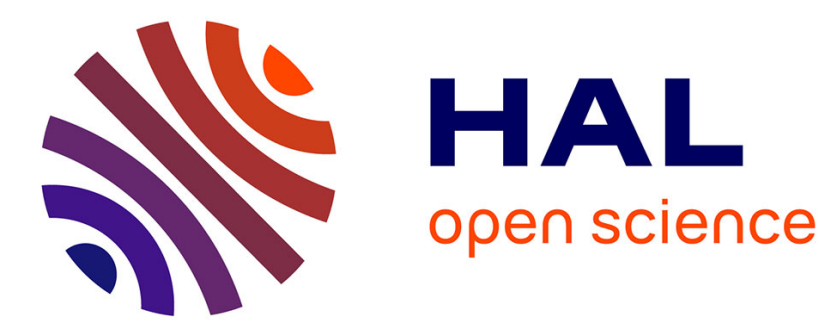

\title{
Comparative analysis of thermally modified and native spruce loaded perpendicular to the grain
}

\author{
Alexander Pfriem, Beate Buchelt, Mario Zauer, André Wagenführ
}

\section{To cite this version:}

Alexander Pfriem, Beate Buchelt, Mario Zauer, André Wagenführ. Comparative analysis of thermally modified and native spruce loaded perpendicular to the grain. European Journal of Wood and Wood Products, 2010, 68 (3), pp.267-270. 10.1007/s00107-010-0457-3 . hal-00605263

\section{HAL Id: hal-00605263 https://hal.science/hal-00605263}

Submitted on 1 Jul 2011

HAL is a multi-disciplinary open access archive for the deposit and dissemination of scientific research documents, whether they are published or not. The documents may come from teaching and research institutions in France or abroad, or from public or private research centers.
L'archive ouverte pluridisciplinaire HAL, est destinée au dépôt et à la diffusion de documents scientifiques de niveau recherche, publiés ou non, émanant des établissements d'enseignement et de recherche français ou étrangers, des laboratoires publics ou privés. 
Ejwwp457_source

\title{
Comparative analysis of thermally modified and native spruce loaded perpendicular to the grain
}

\author{
Alexander Pfriem ()), Beate Buchelt, Mario Zauer, André Wagenführ \\ Technische Universität Dresden, Institute of Wood and Paper Technology, 01062 \\ Dresden, Germany \\ Email: alexander.pfriem@tu-dresden.de
}

This article is dedicated to Gerd Wegener on the occasion of his retirement as professor at the Technische Universität München.

\begin{abstract}
:
The aim of this work was to analyse the material behaviour of thermally modified and native spruce by load applied perpendicularly to the grain. Therefore, thermally modified and native samples were prepared for bending tests with the load in tangential direction. The bending strength in radial direction decreases significantly with the thermal treatment. The fracture surfaces in the tangential section of the bending samples after testing were analysed with a scanning electron microscope. For native samples, the typical failure was found in the intercellular area. For thermally modified samples, failure of the entire cell wall was observed. The material behaviour is more brittle, as demonstrated by the load-deflection curves, but also by anatomical studies of the fracture surfaces.
\end{abstract}

\section{Vergleichende Analyse von thermisch modifizierter und nativer Fichte bei Beanspruchung quer zur Faserrichtung}

Zusammenfassung

Ziel dieser Arbeit war es, das Materialverhalten thermisch modifizierter und nativer Fichte bei Beanspruchung quer zur Faserrichtung zu analysieren. Hierfür wurden thermisch modifizierte und native Proben in Biegeversuchen in tangentialer Belastungsrichtung geprüft. Durch die thermische Behandlung sinkt die Biegefestigkeit in radialer Richtung signifikant. Die Tangential-

Bruchflächen der Biegeproben wurden nach dem Test mit einem Rasterelektronenmikroskop untersucht. Bei nativen Proben wurde das typische Versagen im interzellulären Bereich gefunden. Bei thermisch modifizierten Proben wurde dagegen ein Versagen der gesamten Zellwand beobachtet. Das Materialverhalten thermisch modifizierter Hölzer ist spröder als das von nativen Hölzern, wie die Last-Verformungs-Kurven, aber auch die anatomischen Untersuchungen der Bruchflächen gezeigt haben. 
Ejwwp457_source

\section{Introduction}

Thermal modification of wood aiming at achieving better dimensional stability and increased decay resistance is the commercially most advanced modification process (Hill 2006). This process modifies certain structural, mechanical, physical, and chemical wood properties (Boonstra and Tjeerdsma 2006; Windeisen et al. 2007), resulting in increased dimensional stability (Popper et al. 2005) and durable resistance to fungi and microorganisms (Boonstra et al. 2007; Weiland and Guyonnet 2003) on the one hand, and discolouration (Bekhta and Niemz 2003), strength loss (Borrega and Kärenlampi 2008) and a significant odour (Peters et al. 2008), on the other hand.

Apart from degradation reactions of wood components, also changes in the anatomical structure, such as lateral shifts or dislocations in the S1 wall, can be found as a result of thermal modification (Fengel 1966). The fracture surfaces in transverse planes are typically analysed with anatomical studies, since the stress occurs in fibre longitudinal direction. In comparison with unmodified samples, the heat-treated material fracture surfaces are consistent with abrupt failure (Birkinshaw and Dolan 2009). The fracture surface of the heat-treated samples show only very few pulled-out fragments and clear-cut cell walls (Reiterer and Sinn 2002).

The fracture and material behaviour in the tangential plane, as it occurs when wood fibre direction is perpendicular to the load has not been the subject of such investigations. The aim of this work was to analyse the material behaviour of modified spruce in the tangential section in comparison to the unmodified twin samples.

\section{Materials and Methods}

The spruce (Picea abies (L.) Karst.) specimens used were taken from a blank of a sounding board. The advantage is that there are directly adjacent twins with identical annual rings. One half of the blank was slightly thermally modified $\left(180^{\circ} \mathrm{C}\right.$ in a dry three-stage heat treatment process from the company Thermoholz Austria) and was analysed in comparison with the respective unmodified sample. 


\section{Figure 1}

The samples were prepared for 3-point-bending tests with load applied in tangential direction as shown in Figure 1. Accordingly bending strength and Young's modulus were determined in radial direction perpendicular to the grain. The sizes of the test samples were: length in radial direction $200 \mathrm{~mm}$, width in longitudinal direction $10 \mathrm{~mm}$, thickness in tangential direction $3 \mathrm{~mm}$. The test samples were conditioned to $22^{\circ} \mathrm{C}$ and $60 \%$ relative humidity and remained constant during the test procedure. Each test series comprised 12 specimens. In order to analyse a significant difference between the mechanical properties, an „analysis of variance test“ (ANOVA-test) was carried out. The level of significance was 0.05 .

The fracture surfaces in the tangential section of the bending samples after testing were analysed using a scanning electron microscope (Jeol T330A).

\section{Results and Discussion}

\section{Figure 2 \\ Figure 3 \\ Figure 4}

The results from the 3-point-bending tests are shown in Figures 2 and 3 as Box Plots displaying 5-point summaries (median, the two quartiles and the two extreme values). The bending strength in radial direction by load applied perpendicularly to the grain decreases significantly with the thermal treatment ( $P$ $=0.007)$. As expected and as previously described (Pfriem and Wagenführ, 2008), a significantly higher Young's modulus for slightly thermally modified samples could be proven ( $\mathrm{P}=1.11-\mathrm{E} 16)$. Comparison of the load-deflection curves in Figure 4 proves these results. Thermally modified samples show a decrease of deflection, and thus the strain under load perpendicular to the grain is reduced.

\section{Figure 5}


Ejwwp457_source

Figure 5 shows the typical location of failure: for all specimens the failure was observed in the first rows of the earlywood very close to the annual ring boundary. Partially, the thermally modified and unmodified samples failed even in the same annual ring (example shown in Figure 5).

Figure 6a shows a typical tangential fracture surface of native wood. Figure $6 \mathrm{~b}$ shows the same situation in the corresponding modified twin sample at the same magnification (500x). For native samples, the typical failure could be found more frequently in the cell wall. One explanation could be that the S1-wall has the lowest resistance to splitting (Zimmermann et al. 1994). For thermally modified samples, a failure of the entire cell wall was found with higher probability. Figures $7 \mathrm{a}$ and $\mathrm{b}$ show details of fracture surfaces. The fracture surfaces of the modified material appear much more brittle as shown in detail in Figure 8.

\section{Figures 6a and $b$ Figures $7 a$ and $b$ Figure 8}

Structural changes in the S1- and S2-walls, such as lateral shifts or dislocations in the S1 wall, as described by Fengel (1966), could not be found. However, changes evidently occur. The authors suggest that the degradation of hemicelluloses, as described by Pfriem et al. 2009 (modification of spruce at $180^{\circ} \mathrm{C}$ showed halving of the hemicelluloses content), results in a change of the fracture and material behaviour in the tangential plane.

\section{Conclusion}

A weak thermal modification results in a detectable change of the material behaviour by load perpendicular to the grain. The material behaviour is more brittle, as demonstrated by the load-deflection curves, but also by anatomical studies of the fracture surfaces. For native samples, the typical failure can be found more frequently in the cell wall, meanwhile for thermally modified samples a failure of the entire cell wall was found with higher probability. As one result for thermally modified wood, the degradation of hemicelluloses results in a change of the material behaviour in the tangential plane. 
Ejwwp457_source

\section{Acknowledgements}

This publication is based on results and tests financially supported by the German Research Foundation (DFG WA 1540/7-2). The authors thank Mr. E. Bäucker from the Institute of Forest Utilization and Forest Technology at the Technische Universität Dresden who carried out the SEM analysis.

\section{References}

Bekhta P, Niemz P (2003) Effect of high temperature on the change in color, dimensional stability and mechanical properties of spruce. Holzforschung 57:539-346

Birkinshaw C, Dolan S (2009) Mechanism of Strength Loss in Heat Treated Softwoods. Proceedings of the $4^{\text {th }}$ European Conference on Wood Modification, Stockholm, Sweden, 337-343

Boonstra M J, Tjeerdsma B (2006) Chemical analysis of heat treated softwoods. Holz Roh Werkst 64: 204211

Boonstra M, Acker J, Kegel E, Stevens M (2007) Optimisation of a two-stage heat treatment process: durability aspects. Wood Sci Technol 41: 31-57

Borrega M, Kärenlampi P P (2008) Mechanical behavior of heat-treated spruce (Picea abies) wood at constant moisture content and ambient humidity. Holz Roh Werkst 66: 63-69

Fengel D (1966) Über die Veränderung des Holzes und seiner Komponenten im Temperaturbereich bis $200^{\circ} \mathrm{C}$ - Dritte Mitteilung: Thermisch und mechanisch bedingte Strukturänderungen bei Fichtenholz. Holz Roh Werkst 24: 529-536

Hill, C A S (2006) Wood Modification. Chemical, Thermal and Other Processes, John Wiley and Sons Ltd, Chichester

Lange N (2003) Verarbeitung von Fokusebenenstapeln in der Mikroskopie. Mikrokosmos 92: 305-311

Peters J, Fischer K, Fischer S (2008) Characterization of emissions from thermally modified wood and their reduction by chemical treatment. BioRes 3: 491-502

Pfriem A, Wagenführ A (2008) Feuchtigkeitsabhängigkeit des Elastizitätsmoduls thermisch modifizierter und nativer Fichte (Picea abies (L.) Karst.). Holz Roh Werkst 66: 77-79

Pfriem A, Zauer M, Wagenführ A (2009) Alteration of the pore structure of spruce (Picea abies (L.) Karst.) and maple (Acer pseudoplatanus L.) due to thermal treatment as determined by helium pycnometry and mercury intrusion porosimetry. Holzforschung 63: 94-98

Popper R, Niemz P, Eberle G (2005) Untersuchungen zum Sorptions- und Quellungsverhalten von thermisch behandeltem Holz. Holz Roh Werkst 63: 135-148

Reiterer A, Sinn G (2002) Fracture Behaviour of Modified Spruce Wood: A Study Using Linear and Non Linear Fracture Mechanics. Holzforschung 56: 191-198

Weiland J J, Guyonnet R (2003) Study of chemical modifications and fungi degradation of thermally modified wood using DRIFT spectroscopy. Holz Roh Werkst 61: 216-220

Windeisen E, Strobel, C, Wegener G (2007) Chemical changes during the production of thermo treated beech wood. Wood Sci Technol 41: 523-536

Zimmermann T, Sell J, Eckstein O (1994) Rasterelektronenmikroskopische Untersuchungen an

Zugbruchflächen von Fichtenholz. Holz Roh Werkst 52: 223-229 
Ejwwp457_source

\section{Figures}

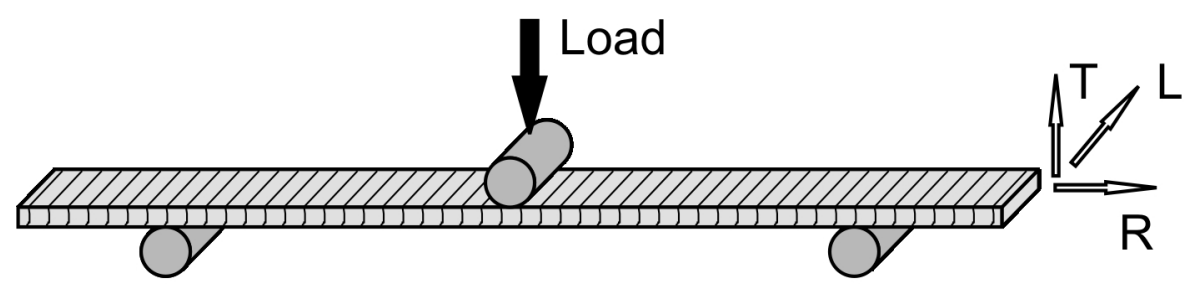

Fig. 1 Orientation of the cutting directions in the specimen for the 3-point bending test Abb. 1 Orientierung der Schnittrichtungen in der Probe beim 3-Punkt-Biegeversuch

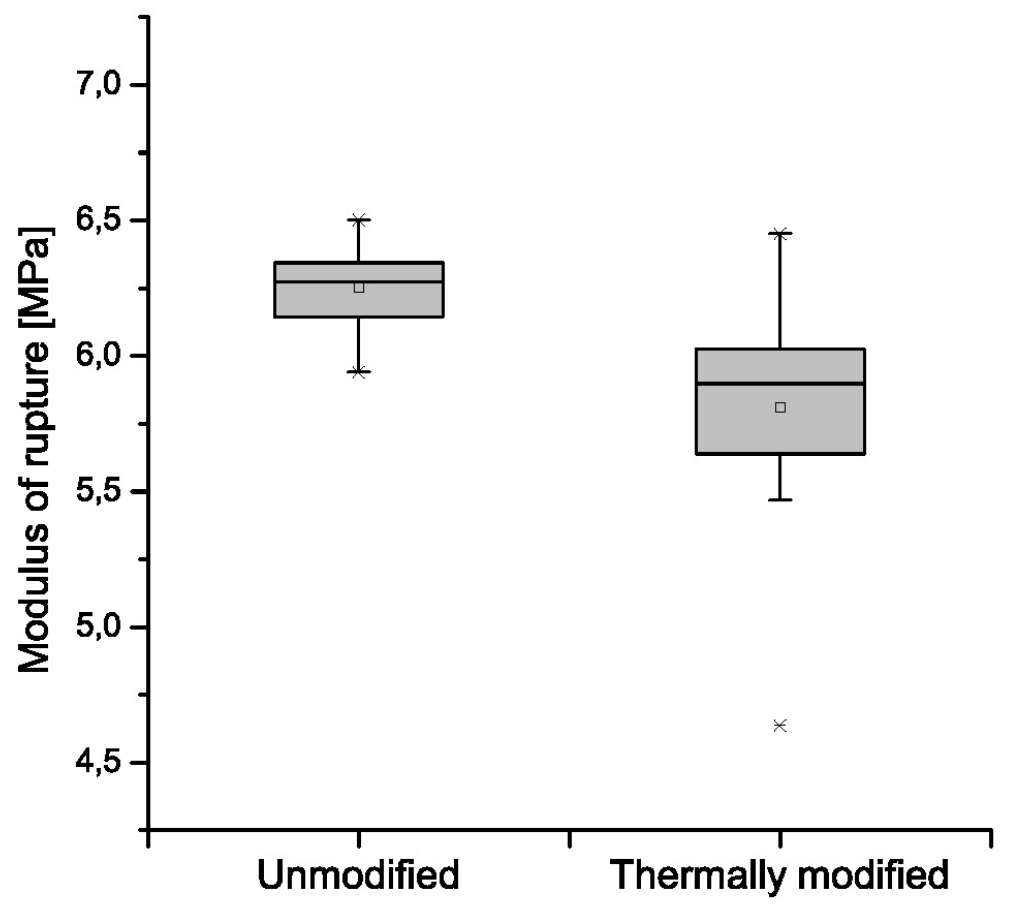

Fig. 2 Influence of thermal modification on the modulus of rupture (MOR) tested in 3-point bending test in radial direction

Abb. 2 Einfluss der thermischen Modifikation auf die Biegefestigkeit im 3-Punkt-Biegeversuch bei Belastung in radialer Richtung 
Ejwwp457_source

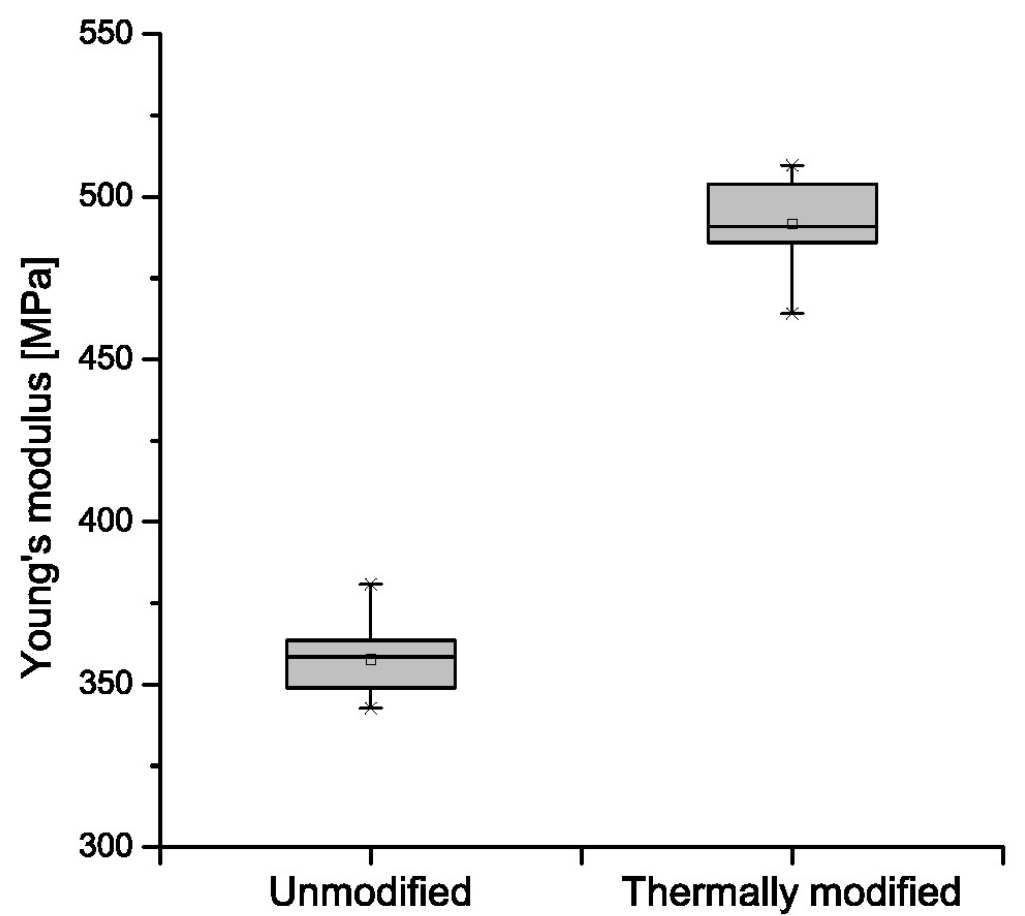

Fig. 3 Influence of thermal modification on the modulus of elasticity tested in 3-point bending test in radial direction

Abb. 3 Einfluss der thermischen Modifikation auf den Biegeelastizitätsmodul im 3-Punkt-

Biegeversuch bei Belastung in radialer Richtung 
Ejwwp457_source

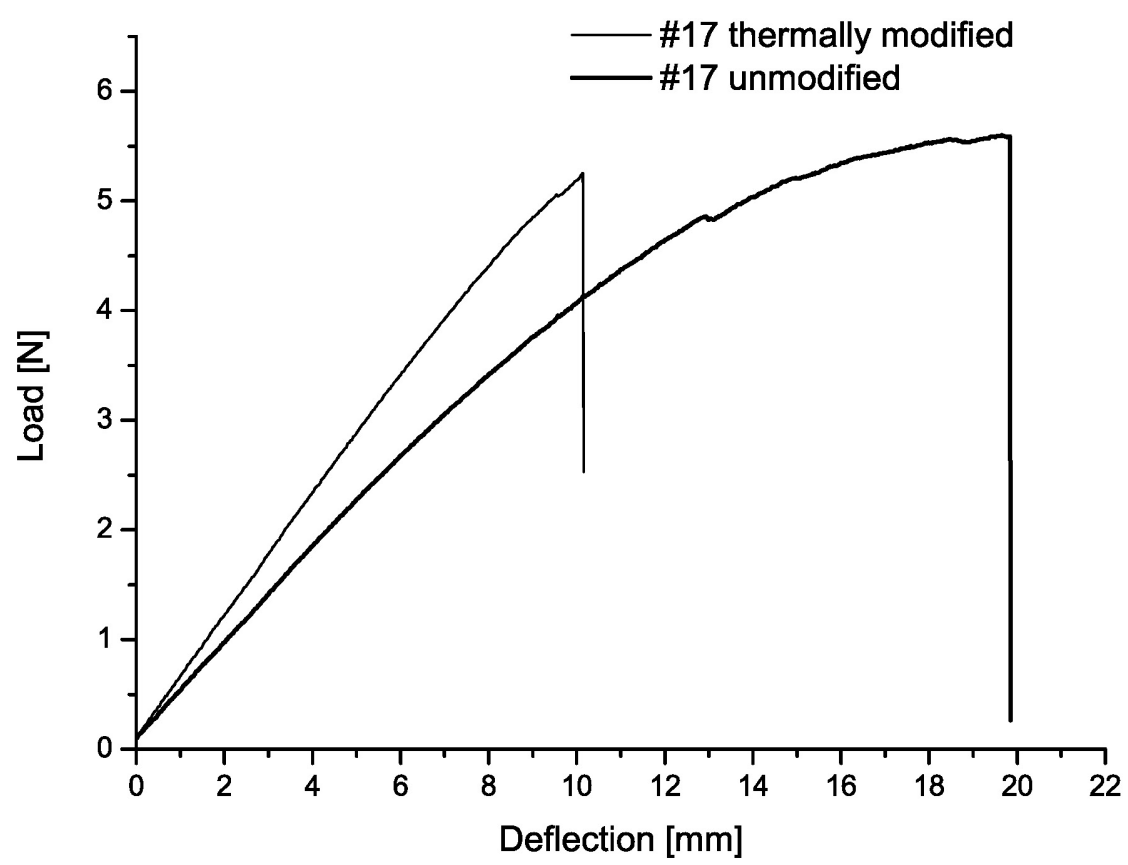

Fig. 4 Load-deflection curves of thermally modified (thin line) and unmodified (bold line) loaded perpendicular to the grain tested in 3-point bending test

Abb. 4 Kraft-Durchbiegungs-Diagramme von thermisch modifizierten (dünne Linie) und unmodifizierten Proben (dicke Linie) im 3-Punkt-Biegeversuch bei Belastung quer zur Faserrichtung

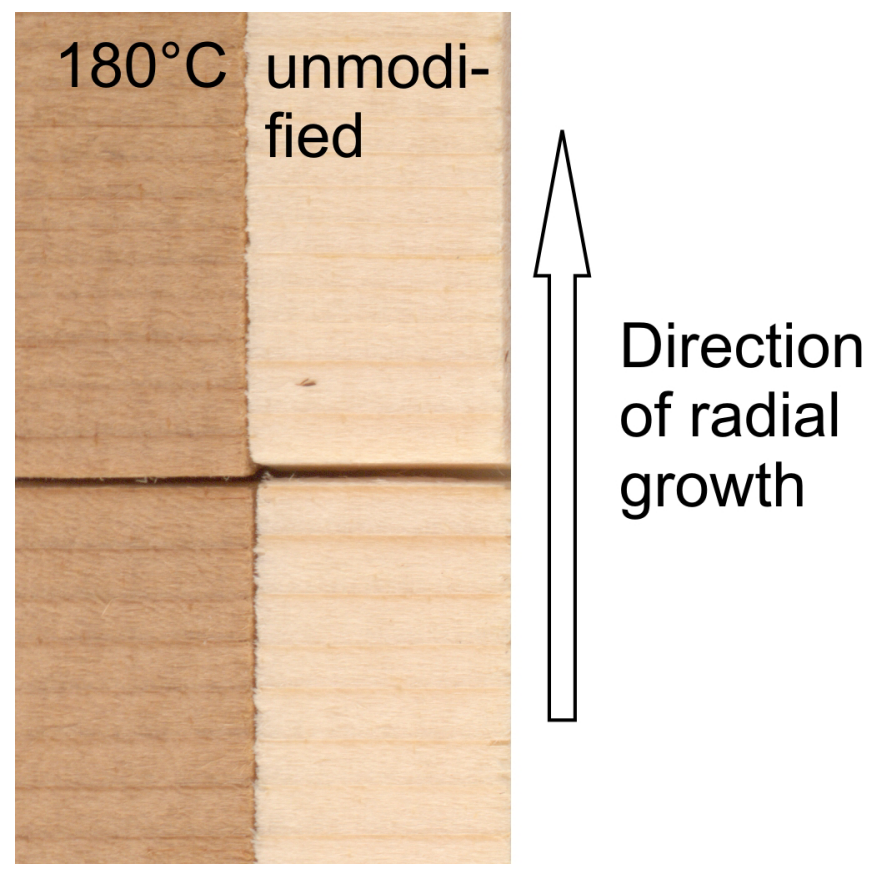

Fig. 5 Macroscopic failure image of sample 17

Abb. 5 Makroskopisches Bruchbild der Probe 17 
Ejwwp457_source
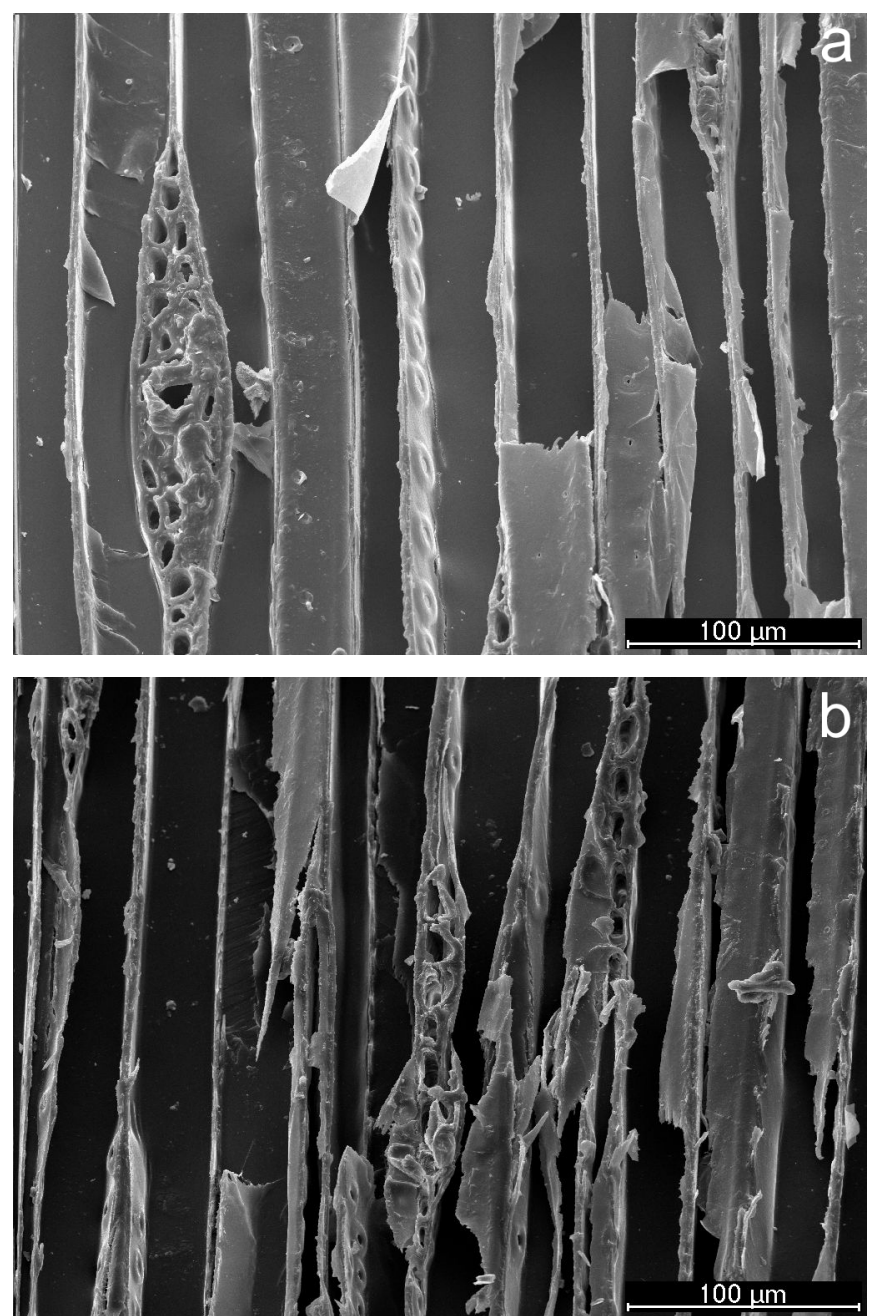

Fig. 6 Fracture surface of native (a) and modified (b) spruce in tangential plane Abb. 6 Bruchfläche von nativer (a) und modifizierter (b) Fichte in tangentialer Ebene 

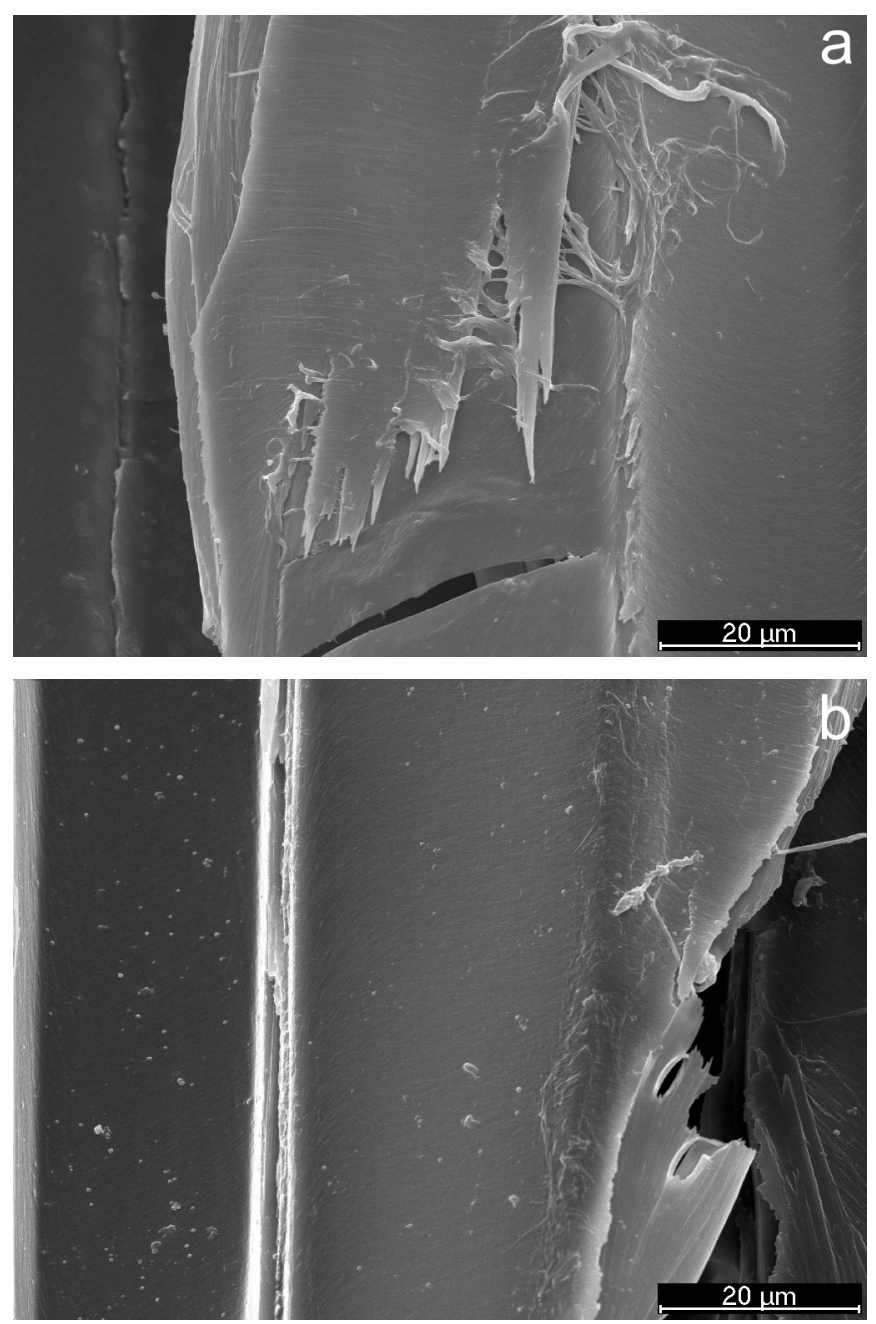

Fig. 7 Detail of a fracture surface of native (a) and modified (b) spruce in tangential plane Abb. 7 Detail einer Bruchfläche von nativer (a) und modifizierter (b) Fichte in tangentialer Ebene

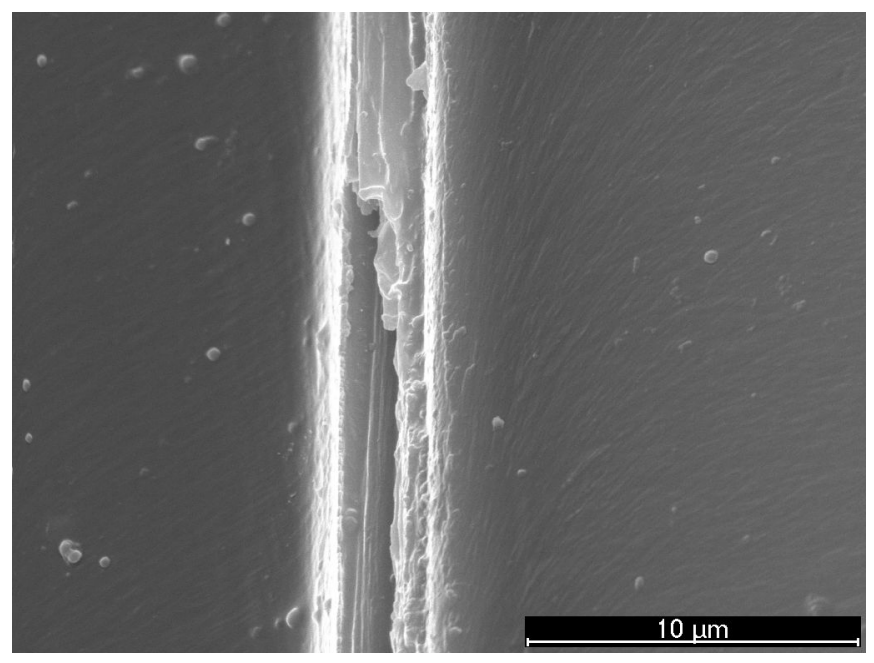

Fig. 8 Detail of the cell wall of modified spruce in tangential plane

Abb. 8 Detail der Zellwand der modifizierten Fichte in tangentialer Ebene 